\title{
Does Fiscal Decentralization in Indonesia have Asymmetrical Information?: Principal-Agent Model, Primal-Dual, and a Neural Network Analysis
}

\author{
By: \\ Kun Haribowo \\ Regional Economic Development, Economics and Business Department, Vocational School, \\ Gadjah Mada University \\ Email: kunharibowo@gmail.com
}

\begin{abstract}
In reality, subnational governments suffer from moral hazard, creating uncertainty which, in turn, causes economic inefficiency. The behavior of subnational governments cannot be observed by the central government. An analysis which takes into account this phenomenon is therefore needed. Decentralization implies delegating authority from central government to subnational governments. In this study, the subnational government is represented by the local government. This study utilizes a model of principal-agent. The central government acts as a principal who delegates fiscal authority to subnational governments who act as agents. By applying principal-agent model, we can use the primal-dual approach to analyze both revenue and expenditure assignment associated with the tax effort of the subnational governments. The result from artificial neural network approach shows that asymmetric information between central and subnational governments exists in Indonesia.
\end{abstract}

Keywords: Artificial Neural Network, Fiscal Decentralization, Local Tax Effort, PrimalDual, Principal-Agent.

\begin{abstract}
ABSTRAK
Pada kenyataannya, pemerintah daerah mengalami moral hazard, menciptakan ketidakpastian yang pada gilirannya menyebabkan inefisiensi ekonomi. Perilaku pemerintah daerah tidak dapat diamati oleh pemerintah pusat. Oleh karena itu, diperlukan analisis yang memperhitungkan fenomena ini. Desentralisasi menyiratkan pendelegasian wewenang dari pemerintah pusat ke pemerintah daerah. Dalam studi ini, pemerintah daerah diwakili oleh pemerintah daerah. Penelitian ini menggunakan model principal-agent. Pemerintah pusat bertindak sebagai kepala yang mendelegasikan kewenangan fiskal kepada pemerintah daerah yang bertindak sebagai agen. Dengan menerapkan model principal-agent, kita dapat menggunakan pendekatan primal-dual untuk menganalisis baik tugas pendapatan dan pengeluaran terkait dengan upaya pajak dari pemerintah daerah. Hasil dari pendekatan artificial neural network menunjukkan bahwa informasi asimetris antara pemerintah pusat dan daerah ada di Indonesia.
\end{abstract}

Kata Kunci: Artificial Neural Network, Desentralisasi Fiskal, Upaya Pajak Daerah, PrimalDual, Principal-Agent.

\section{INTRODUCTION}

The role of the government is the redistribution of income, the provision of public goods and social protection (Gramlich, 1990). Governments perform these functions for all citizens. When the area and population is too large, it is difficult for government in carrying out these functions, and then the multilevel system of government is indispensable. Multi-level system of government, like decentralization, does not necessarily mean shifting the systems, but rather as a response according to the divergent 
needs of citizens in different locales (Lee et al., 2008). To reduce vertical and horizontal imbalances between the central and the subnational governments as well as other subnational governments, the central government also transfers intergovernmental grants to the subnational governments. In this study, the subnational government is represented by the local government, i.e. regency and city.

In Indonesia, in 2019, the value of the transfer of funds to the local governments are totaled Rp832,3 trillion. The provision of substantial funds without the supervision of execution can lead to abuse. There are potential conflicts of interest that can lead to agency problems (Eisenhardt, 1989). In fiscal decentralization, the agency problem occurs when local governments who receive the authority, act as agents, has information that is not known by central government who delegates fiscal authority, acts as a principal. Local governments have more information at their own budget rather than the central government. In this condition the local government, potentially, does not act for the central government interest or become self-interested.

The differences in interests between the principal and the agent associated with central and local government relations are interesting and challenging to learn. This is the focus of this study. When the central budget to local governments becomes larger while its outcome is small, then the transfer of funds to local government will be compensated by the discretion in tax collection and using its budget to local authorities. However, the principal-agent interest conflict can make local governments depend on central government transfers. This is due to lack of balance funds transfer policies related to local government performance. As a result, moral hazard can occur. It causes a high dependence on central funding and the sub-optimal effort to increase local revenue. Low local government revenue would be an obstacle in the provision of public services.

\section{LITERATURE REVIEW}

\section{Fiscal Decentralization in Indonesia}

Researches on the implementation of decentralization in Indonesia have been carried out. One of them is Ferazi (2000), who explained that in the current reform period the concept of federalism during the colonial era resurfaced although not discussed openly, inclusively, and equally. Although the concept of federalism is less developed in the short term, there is potential for the structural growth in Indonesia. Brodjonegoro and Martinez-Marquez (2002) explains that the implementation of decentralization in Indonesia has experienced significant progress. While Smith (2008) argues that the implementation of decentralization in Indonesia, there are still political uncertainty, in which the influence of the politicians is still prevalent. Fadliya and McLeod (2010) conducted an analysis of the fiscal equalization when some central authorities are delegated to the regions. According to them, a decentralized system was introduced too rushed and lack of clarity. So, the results are not as desired. According to Jaya (2010), the policy of decentralization and regional autonomy in Indonesia still has not fully met the expectations theory. Other researchers, Shah (2012) explains that over the last decade, Indonesia has transformed itself from a centralized to a decentralized system of government in which local governments are given the responsibility of spending while maintaining a centralized tax system. To finance the expenditure decentralization of local government, Indonesia implemented a new system of intergovernmental finance.

The data indicate that the local revenues of taxes and levies sector are still relatively small. Even for counties and cities, it actually decreases compared to total revenues in the local government budget (APBD). Supposedly, with the grant of discretion in local revenues, the local government can more easily increase taxes and levies. However, granting of discretion shows a decrease of local revenues in taxes and levies. Local financial dependence on the central government is becoming increasingly high. The percentage of the regency and city revenues after fiscal decentralization has decreased compared to before the fiscal decentralization (Directorate General of Fiscal Balance, MOF, 1997-2010). The data can be described in the table below. 
Table 1. Regencies and Cities Revenues After and Before Fiscal Decentralization

\begin{tabular}{|c|c|c|c|c|c|c|c|}
\hline Local Government & Year & Decentralization & Total Revenue & $\begin{array}{c}\text { Local Tax } \\
\text { Revenue }\end{array}$ & Percentage & $\begin{array}{c}\text { Local Retribution } \\
\text { Revenue }\end{array}$ & Percentage \\
\hline \multirow{3}{*}{ Regencies/Cities } & 1997 & Before & $15,246,980.94$ & $760,291.15$ & 4.99 & $927,704.51$ & 6.08 \\
& 1998 & & $19,126,468.47$ & $943,814.84$ & 4.93 & $957,074.55$ & 5.00 \\
\cline { 2 - 8 } & 2006 & \multirow{2}{*}{ After } & $208,506,746,183$ & $4,628,027,870$ & 2.22 & $4,594,277,558$ & 2.20 \\
& 2007 & & $244,309,131,163$ & $5,380,379,942$ & 2.20 & $5,388,033,569$ & 2.21 \\
\hline
\end{tabular}

Central government expenditure in the form of a transfer of funds to the regions is dominated by the quite high fund balance, that the state budget in 2019 is planned for Rp832,3 trillion, or nearly half the value of the Government Budget (Financial Memorandum, 2019). Therefore, the transfer of funds to the local government with granting of discretion on taxes and levies is expected to increase local tax effort and reduce the financial burden of the central government.

\section{Principal-Agent Model for Decentralization in Indonesia: Primal-Dual}

In microeconomics, the optimization problem can be represented in two different paths primal and dual. The selection of optimization problem depends on the information obtained in the process of achieving optimization solutions. Primal dual concept has become a standard optimization solution in the micro-economic literature. In the approach to the consumer, the primal concept aims to maximize the utility function of consumers with budget constraints (subject to budget constraint) in order to obtain an optimal solution of the primal problem. Such concepts will generate Marshallian demand solutions. In the dual concept, consumers will minimize the expenditure function with the constraints of his utility function (subject to utility function), so an optimal solution for the dual problem will be obtained. The optimal solution is obtained through a dual concept generating Hicksian demand solutions.

Both the optimal solutions for the primal dual concept will yield the same value. It means finding the optimal solution through the concept of the primal or the dual concept of an optimal solution will result the same. This condition occurs only when there is symmetrical information on both primal and dual approaches. The objective function of the primal approach will be a constraint on the dual approach, and vice versa, the objective function in the dual approach will be a constraint on the primal approach. If it is not symmetric, the optimal solution will be different from the primal and dual approaches.

The basic model used in this study is the principal-agent approach, modified model of economic information that is performed by Varian (1992), Furubotn and Richter (1998), and Snyder and Nicholson (2008) through the concept of primal-dual. In the appropriate parsimony principle in the formulation of economic phenomena into the equation, all local revenues are derived from the fund balance and the local revenue, denoted as T. Fund balance is divided into non-share transfer, $a$, and a system of revenue sharing (share transfer), $b$. The existence of local government efforts to increase revenue through local taxes, will produce outcomes as a result, of $Q$, where the outcome is going up or down in proportion to the effort of the agent, $e$. The central government wants a condition in which the transfer of the balance of funds will go down as the increase in local revenue by giving a wider discretion in taxes and levies. More explanation of the above can be formulated in the following equation:

Total revenues (budget constraint) received by local agents (local government), $T$, is:

$$
T=a+b Q
$$


When agents do the effort, it will cause costs (Varian (1992) and Snyder Nicholson (2008)) for:

$$
c=\frac{1}{2} \alpha e^{2}
$$

These costs arise because of the intensification of local revenues, such as the process of making regulations, education and training of human resources in the region, assisting policy-making, and other activities that support the increasing of local revenue.

First order condition of equation (2.2) when the maximum effort:

$$
\frac{d c(e)}{d e}=\alpha e
$$

At the condition of maximum effort, the effort is equal to the marginal marginal outcome, where $\alpha$ is a constant, so that:

$$
Q=e
$$

\section{Agent Utility}

Agent utility is total revenue minus the cost of the effort:

$$
U=T-c
$$

or

$$
U=a+b Q-\frac{1}{2} \alpha e^{2}
$$

Agent will maximize utility with the constraint $Q=e$, then the equation becomes:

$$
U=a+b e-\frac{1}{2} \alpha e^{2}
$$

First order condition of agent utility for e is:

$$
b-\alpha e=0
$$

or

$$
e=\frac{b}{\alpha}
$$

This is the incentive compatibility for the principal under uncertainty conditions, meaning that the local government under conditions of uncertainty should do the value of effort requirements desired by the central government. 


\section{Outcome Principal}

Principal outcome function, $R$, is:

$$
R=Q-T
$$

or

$$
R=(1-b) e-a
$$

\section{Primal Solution}

$$
\underset{a, b, e}{\operatorname{Max}} U=a+b \cdot e-\frac{1}{2}\left(\alpha e^{2}\right)
$$

Subject to:

$$
\begin{gathered}
Q_{p} \leq(1-b) e-a \\
e \leq \frac{b}{\alpha}
\end{gathered}
$$

Kuhn-Tucker model for this equation is:

$$
U=a+b \cdot e-\frac{1}{2} \alpha(e)^{2}+\gamma(1-b) e-a
$$

Subtitution second constraint to equation (3.12) will be obtained:

$$
U=a+\frac{1}{2} \frac{(b)^{2}}{\alpha}+\gamma\left(-a+\frac{b-(b)^{2}}{\alpha}\right)
$$

Partial derivation for objective function becomes:

$\frac{\partial U}{\partial a}=1-\gamma$

$\frac{\partial U}{\partial b}=\frac{b}{\alpha}+\frac{\gamma(1-2 b)}{\alpha}$

$\frac{\partial U}{\partial \gamma}=-a+\frac{b-(b)^{2}}{\alpha}$

From above equation, can be known variable for $\gamma$ :

$$
\begin{aligned}
& 1-\gamma=0 \\
& \gamma=1
\end{aligned}
$$


Subtitution equation (2.16) to equation (2.14) can be obtained:

$$
\begin{aligned}
& \frac{b}{\alpha}+\frac{\gamma(1-2 b)}{\alpha}=0 \\
& \frac{b}{\alpha}+\frac{1-2 b}{\alpha}=0 \\
& b=1
\end{aligned}
$$

Because:

$$
e=\frac{b}{\alpha}
$$

then:

$$
e=\frac{1}{\alpha}
$$

\section{Dual Solution}

$$
Q_{p}=(1-b) e-a
$$

Subject to:

$$
\begin{aligned}
& U \leq a+b Q-\left(\frac{1}{2} \alpha e^{2}\right) \\
& e \leq \frac{b}{\alpha}
\end{aligned}
$$

Equation in first constraints is participation constraint and in second constraints is incentive compatibility. Kuhn-Tucker model for this equation is:

$$
\begin{aligned}
& L(a, b, e, \lambda)=(1-b) e-a+\lambda\left(a+b e-\left(\frac{1}{2} \alpha e^{2}\right)\right) \\
& \frac{\delta L}{\delta a}=0, \lambda-1=0 \\
& \frac{\delta L}{\delta b}=0, \lambda e-e=0 \\
& \frac{\delta L}{\delta e}=0,1-b+\lambda(b-\alpha e)=0 \\
& \frac{\delta L}{\delta \lambda}=0, a+b e-\left(\frac{1}{2} \alpha e^{2}\right)=0
\end{aligned}
$$


From partial derivation we can obtain:

$$
\begin{aligned}
& \lambda(b-\alpha e)=b-1 \\
& \text { because } \lambda=1, \text { then: } \\
& b-\alpha e=b-1 \\
& e=\frac{1}{\alpha}
\end{aligned}
$$

Value of effort, $e=1 / \alpha$, is the same in both solutions, primal and dual. In this condition, the central government, as principal, has the same information with the information held by the local government as an agent. The central government knows all the efforts made by the local government. Different things happen in conditions of asymmetric information. If the values of effort, $e$, is not same, the central government, as the principal, does not have the same information with the local authorities, acting as agents. The explanation proves that the primal-dual can be applied for the implementation of fiscal decentralization in Indonesia between the central government as a principal with the local government as an agent. These results need to be tested with data on the implementation of decentralization in Indonesia. Tests carried out using artificial neural networks analysis.

\section{Artificial Neural Network (ANN)}

Artificial neural network (ANN) hereinafter called ANN inspired by biological tissues of the human brain, with the smallest processing units called neurons, which is estimated as many as 1,013 neurons. This simple model is further developed to a rather complicated model with multi-layer perceptron (MLP) or also known as a feed-forward neural network (FFNN) which is very flexible to model nonlinear regression, discriminant analysis, and data reduction models.

ANN method is a new method in the science of economics, although in other areas already applied. ANN method is the application of the human nervous system. It is generalized into a mathematical model. The advantage in the use of neural networks as a research analysis is the existence of the layer in the process of incorporating the input to obtain the results. With the layer, the model is then able to perform a more precise estimate, so that the accuracy of the prediction is higher when compared with other models. In addition, the structure of the network architecture of ANN will create a model to be more flexible for the use in variety of requirements, both linear and nonlinear models. In simple terms, the comparison of ANN models with statistical models such as regression can be described in a simple figure below.
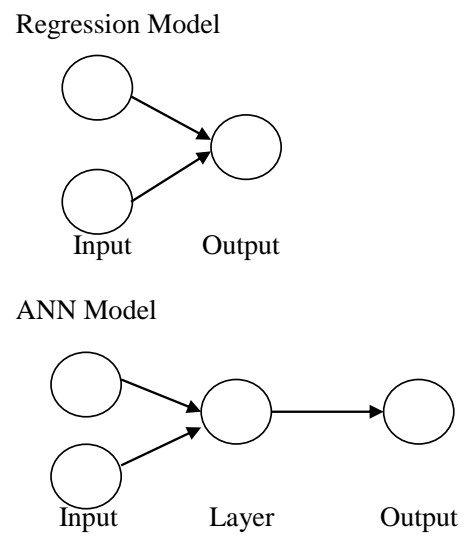

Figure 1. The Comparison of ANN Models with Statistical Models 


\section{Artificial Neural Network (ANN) for Social Research}

ANN has been widely used as an analytical tool in various studies. However, its use is still widely used in science than in the social science researches. In the social sciences, particularly economics, several studies indicate that the ANN models have a smaller error than the model analysis with statistical methods, such as Ordinary Least Square (OLS), Multiple Regression Analysis, Linear Probability Model (Chen (2005)). Hill et al. (1996) using neural networks for forecasting the data series is compared with the model of statistical forecasting as deseasonalized single exponential smoothing, Box-Jenkins, and deseasonalized Holt's exponential smoothing. It shows that the model of ANN is better than the traditional model in terms of MSE as a measure of goodness of fit.

Bharat et al. (1997) suggested that ANN models consistently outperform on logistic regression models to predict the accuracy of any corporate bankruptcies of new business strategies. Meanwhile, Binner et al. (2004) predicted the occurrence of inflation and compared models of Vector Autoregressive (VAR) and Recurrent Neural Network (RNN) for the same data, in which the results showed that the RNN model error value is smaller than the VAR model. Mirmirani and Li (2004) also predict the movement of oil prices in the US by using the VAR model and Back Propagation NN for comparison, which shows that the NN models have a smaller error value than the VAR model.

\section{METHODS}

\section{Analysis of the Decentralization in Indonesia Using Neural Networks}

The estimation method used in the study is ANN. The use of this method is based on several previous studies that showed that the value of the error in the estimation of ANN is smaller than the statistical model with econometric analysis. However, almost all studies in the social sciences, conducted for the data series, use ANN, while the use of panel data using principal-agent models like in this research is rare or even perhaps not used.

The method chosen in this study is the ANN, using the architecture of multi-layer perceptron (MLP) or known by other terms of feed-forward neural network (FFNN). The reason for choosing this method is because the statistical models, FFNN, is very flexible for different types of data and analytical models, such as regression, nonlinear regression, discriminant analysis, and data reduction models (Subanar, 2005). Analysis was conducted using back propagation and training with LavenbergMarquardt method. Initial data input is transformed into a normal distribution, corresponding binary sigmoid function as the activation requirement back propagation method (mapminmax). Network architecture in this study contains one hidden layer and one output layer with a selection of the most efficient number of neurons that can be seen in the mean square error (MSE) and the sum square error (SSE). The interpretation of the results, for primal and dual solutions of decentralization in Indonesia, we use the Garson algorithm (Olden and Jackson, 2002).

\section{Estimation Model}

Estimation is carried out in two stages. The first stage is to look for a local tax effort and the second step is to find out whether there is asymmetric information between the central government and the local government using a tax effort proxy. FFNN model in the local tax effort estimation can be formulated in the form of a mathematical equation as follows:

$$
\hat{y}=f_{\bullet}^{\circ}\left[w_{\bullet}^{o} f^{h}\left\{w_{y_{p}}^{h} \cdot x_{y_{p}}+b_{y_{p}}^{h}\right\}+b_{\bullet}^{\circ}\right]
$$

Where,

$\hat{y}=$ response value or target i.e. Local tax-revenue ratio

$f_{.}^{o}=$ activation function of neuron at output layer

$w_{\bullet}^{o}=$ weight from neuron at hidden layer to neuron at output layer 
$x_{y p}=$ input variable, local revenue per capita

$w_{y p}^{h}=$ weight from input to neuron at hidden layer

$b_{y p}^{h}=$ bias from neuron at hidden layer

$f^{h}=$ activation function to neuron at hidden layer

$b_{\bullet}^{o}=$ bias of neuron at output layer

Operational definitions of variables in the first section of the analysis are as follows:

$\hat{y}=$ estimation of the ratio of the output with local revenue. Local revenue comes from local tax sector and admission levy. The output is gross regional domestic product (GRDP).

$\mathrm{x}_{\mathrm{yp}}=$ income per capita i.e. gross regional domestic product (GRDP) per capita.

The second stage of the model is to estimate tax effort with variables of input revenue and expenditure fund:

$$
\hat{e}=f_{\bullet}^{o}\left[w_{\bullet}^{o} f^{h}\left\{\left(w_{t}^{h} \cdot k_{t}+b_{t}^{h}\right)+\left(w_{s}^{h} \cdot l_{t}+b_{s}^{h}\right)\right\}+b_{\bullet}^{o}\right]
$$

Where,

$\hat{e}=$ response value or target, i.e. local tax effort

$f_{.}^{o}=$ activation function of neuron at output layer

$w_{\bullet}^{o}=$ weight of neuron at hidden layer to neuron at output layer

$k_{t}=$ input variable, local revenue

$l_{t}=$ input variable, local expenditure

$w_{y p}^{h}=$ weight from input to neuron at hidden layer

$b_{y p}^{h}=$ bias of neuron at hidden layer

$f^{h}=$ activation function of neuron at hidden layer

$b_{\bullet}^{o}=$ bias of neuron at output layer

Operational definitions of variables in the third section of the analysis are as follows:

$\hat{e}=$ the tax effort is the result of estimated tax collection as a proxy of the potential taxes, which are then compared with the actual.

$k_{t}=$ local revenue from equalization funds transfer and local revenue.

$l_{t}=$ local expenditure from equalization funds transfer and local revenue.

The purpose of estimation of the first stage is to get the local government tax effort in Indonesia. Tax effort resulted from compares the estimation of local tax income and actual tax revenue. Finally, the purpose of estimating the second stage to determine whether there is asymmetric information in the implementation of fiscal decentralization in Indonesia.

\section{Research Data}

The data used in this study include data regencies and cities across Indonesia, which are obtained from the Directorate General of Financial Equalization, Ministry of Finance and the Central Bureau of Statistics. The data contain local tax and levies, Gross Regional Domestic Product (GRDP), GRDP per 
capita, General Allocation Funds (DAU), Special Allocation Fund (DAK), tax-share (DBH Pajak), and natural resources-share (DBH SDA), during 2005-2015 periods to 224 regencies and cities in Indonesia.

\section{RESULT AND DISCUSSION}

Estimation was conducted through the feed forward neural network with a back-propagation method. The training used Lavenberg-Marquard models. Analyses were performed with several hidden layer and output layer. Prior to analysis, the input data was a panel data with 224 cross-section data, eleven series and two variables were converted into a matrix form whose results were of the order matrix $(224 \times 11 \times 2)$ with a total of 4928 observations. Data input were local government revenue and expenditure, and the target was local tax effort. These data then transformed into a normal distribution with binary sigmoid function. After the establishment of the appropriate matrix, the next step was to divide the data into three parts, i.e. 70 percent for training, 15 percent for validation, and 15 percent for testing. The benefit of fit analysis in this section is the minimum errors of mean square error (MSE) and sum square error (SSE). The results of the analysis showed that using the backpropagation method would reach minimum of mean square error (MSE) and the sum square error (SSE) when using certain amount neurons in the hidden layer.

The results of the analysis in the first section (equation 1.21) showed that using the backpropagation method would reach minimum of mean square error (MSE) and the sum square error (SSE) when using four neurons in the hidden layer. MSE and SSE with four neurons in the hidden layer was 0.00816701 and 20.12352291 . The result shows that the parameter of input variable i.e local revenue per capita, $\mathrm{m}=0.5250$ and intercept/constant $=0.0880$. The result of estimation can be made comparison tax effort and GRDP as seen in table 1.

Table 1. Tax Effort Proportion - GRDP per Capita Comparison in 224 Regencies and Cities in Indonesia

\begin{tabular}{|c|c|c|c|c|c|}
\hline & \multicolumn{4}{|c|}{ GRDP per Capita } \\
\hline & & High & Medium & Low & Total \\
\hline \multirow{4}{*}{ Tax Effort } & High & $4,46 \%$ & $3.57 \%$ & $9.82 \%$ & $17.86 \%$ \\
\hline & Medium & $1.79 \%$ & $3.57 \%$ & $9.82 \%$ & $15.18 \%$ \\
\hline & Low & $4.91 \%$ & $11.16 \%$ & $50.89 \%$ & $66.96 \%$ \\
\hline & Total & $11.16 \%$ & $18.30 \%$ & $70.54 \%$ & $100.00 \%$ \\
\hline
\end{tabular}

The table shows that most of the local government regencies and the cities have low tax efforts as much as 66.96 percent. Only 17.86 percent has a high tax effort. Table 1 also show that regions with high per capita GRDP (11.16 percent), 4.46 percent showed high tax efforts, while the rest, 6.7 percent, has moderate efforts to lower taxes. Disturbingly, in regions having low per capita GRDP, most of which, 50.89 percent, have low tax efforts. Indirectly, the table indicates that most of the region has low tax efforts.

The second estimation as show in equation 1.22 results MSE $=0.02393862$, SSE $=33.27468647$, parameter of input variable i.e local revenue and expenditure, $m=0.9181$, intercept, $b=0.0073$, and coefficient $r=0.71$. For interpretation of the results, I use the Garson algorithm (Olden and Jackson, 2002). Garson calculation algorithm for result of equation 1.22 showed the following results:

Table 2. Relative Contribution and Relative Importance Input Variables to Local Tax Effort

\begin{tabular}{|l|c|c|}
\hline \multicolumn{1}{|c|}{ Input Variables } & \multicolumn{1}{|c|}{$\begin{array}{c}\text { Relative } \\
\text { Contribution }\end{array}$} & $\begin{array}{c}\text { Relative } \\
\text { Importance }\end{array}$ \\
\hline Local Revenue & 1.474 & 0.491 \\
\hline Local Expenditure & 1.526 & 0.509 \\
\hline
\end{tabular}


As shown in Table 2 above, the value of the relative importance between revenue and expenditure shows different results. The relative importance value of local revenue of the tax effort is 49 percent, while for regional expenditure is 51 percent. The difference between the relative importance of the two input variables to the efforts of tax is 1.80 percent. Based on the derivation of the equations associated with the tax effort, these differences indicate the occurrence of asymmetric information between the central government as a principal with the local government as agents in the implementation of fiscal decentralization in Indonesia. There are agents who do not act in accordance with the interest of the principal.

Derivation of the equation shows that when there is symmetric information between central and local governments, according to the concept of primal-dual, the value of the agent effort will be the same when seen from the revenue and expenditure side of the budget. However, the data in this essay show the different values. It means there is asymmetric information between principals and agents. Giving discretion on local revenues and expenditures should be a stimulus for the regional economy, it does not necessarily make the region increase its tax effort as the expectations of the central government and fiscal dependence on the national budget have been decreased. Although there has been no standard that measures the magnitude of the degree of information asymmetry, but the difference is not significant enough. Therefore, it can be said that through proxy tax effort, the level of asymmetric information between central and local governments is not too high.

\section{CONCLUSION}

In fiscal decentralization, it may occur conflicts of interest between the central government, as the giver of authority which acts as a principal, with the local government as an agent who received the delegation of authority. The interest of the central government, when delegating authority is to ensure that all programs will run on all local governments. On the other hand, local governments, as an agent, also have an interest in maximizing their own utility. This condition will lead to a situation of uncertainty.

Results from the estimation conclude that there is asymmetric information between central government and local governments. The data indicating that the relative value of the relative contribution or importance shows different values. This condition explains that in terms of tax effort, asymmetric information between the principal or the agent of the central government to local governments in Indonesia occurs. The central government, as the principal, does not know the efforts of local governments to raise taxes on the result, whether it is due to the hard work of the local government or other reasons such as tax regulations, obedience the tax payer, or the performance of tax officials. By knowing the local tax effort, it will be easier for the central government to formulate a transfer fund as fair incentives for local government. Inserting local tax effort variables into this formulation will differentiate region that has worked hard to raise taxes and region where its taxes increase due to mere chance. Within the framework of the financial relationship between central and local governments, local tax effort can be improved by reformulating the mechanism of balancing funds.

The effort of local governments can be used as an outcome indicator in the formulation of government funds balance transfers. Incorporating this indicator into the formulation of equalization funds, means taking into account the interests of central government for the use of these funds by local governments. The higher the effort to increase revenue, the higher the outcome of the central government.

Achievements of higher central government outcomes are marked with the reduction in the fiscal dependence of local governments to the central government and improvements in the public services provided by local government. This is consistent with the mandate of Article 18 of the Constitution of the Republic of Indonesia in 1945, in which the unitary Republic of Indonesia is divided into the provinces, and the province is divided into regencies and cities with the most authority delivered to local government, but the final responsibility of the authority remains on the central government. 


\section{REFERENCES}

Bharat, A. et al. (1997). Performance evaluation of neural network decision models. Journal of Management Information Systems, 14(2), 201-216.

Brodjonegoro, B. \& Martinez-Marquez, J. (2002). An Analysis of Indonesia's transfer system: recent performance and future prospect. Working Paper 02-13, International Studies Program, Andrew Young School of Policy Studies, 1-51.

Binner, J. M. et al. (2004). Tools for non-linear time series forecasting in economics an empirical comparison of regime switching vector autoregressive models and recurrent neural networks. Applications of Artificial Intelligence in Finance and Economics, Advances in Econometrics, 19, 71-91.

Chen, J. (2005). Neural network applications in agricultural economics. Dissertation. Kentucky, United States: University of Kentucky.

Eisenhardt, K. M. (1989). Agent theory: an assessment and review. The Academy of Management Review, 14(1).

Fadliya \& McLeod, R. H. (2010). Fiscal transfers to regional governments in Indonesia. Working Papers in Trade and Development, Arndt-Corden Department of Economics Crawford School of Economics and Government ANU College of Asia and the Pacific, 1-35.

Ferazi, G. (2000). Using the "F" word: federalism in Indonesia's decentralization discourse. Publius, $30(2), 63-85$.

Furubotn, E. G. \& Richter, R. (1998). Institutions and economic theory. Michigan, United States: The University of Michigan Press.

Gramlich, E. M. (1990). The economics of fiscal federalism and its reform: the changing face of fiscal federalism (Swartz \& Peck edition). New York, United States: M. E. Sharpe, Inc.

Hill, M. O. \& Remus, W. (1996). Neural network models for time series. Management Science, 42(7), 1082-1092.

Lee, D. R., Johnson, W. R., \& Philip, J. G. (2008). Public budgeting systems. Massachusetts, United States: Jones and Bartlett Publishers.

Martinez-Vasquez, J. (2002). Asymmetric federalism in the russian federation: cure or poison?. International Study Program Working Paper.

Mirmirani, S. \& Li, H. C. (2004). VAR and neural networks with genetic algorithm in forecasting price of oil: applications of artificial intelligence in finance and economics. Advances in Econometrics, 19, 203-223.

Nicholson-Crotty, S. (2009). Fiscal federalism and tax effort in the American states: report 04-2009. Missouri, United States: University of Missouri Columbia, Institute of Public Policy.

Shah, A. (2012). Toward a more transparent, objective, predictable and simpler (TOPS) system of central financing of provincial-local expenditures in Indonesia. Working Paper: The World Bank, East Asia and the Pacific Region Poverty Reduction and Economic Management Unit, 1-31.

Smith, B. (2008). The origins of regional autonomy Indonesia: experts and the marketing of political interests the origins of regional autonomy in Indonesia, experts and the marketing of political interests. Journal of East Asian Studies, 8, 211-234.

Subanar. (2005). Statistical modeling by using neural networks. Mini Symposia, International Conference on Applied Mathematics (ICAM05), Bandung Institute of Technology.

Varian, H. R. (1992). Microeconomic analysis. New York \& London: Norton. 